National Assessment of Oil and Gas

\title{
Assessment of Undiscovered Oil and Gas Resources in Conventional and Continuous Petroleum Systems in the Upper Cretaceous Eagle Ford Group, U.S. Gulf Coast Region, 2011
}

Using a geology-based assessment methodology, the U.S. Geological Survey assessed means of (1) 141 million barrels of oil (MMBO), 502 billion cubic feet of natural gas (BCFG), and 16 million barrels of natural gas liquids (MMBNGL) in the conventional Eagle Ford Updip Sandstone Oil and Gas Assessment Unit (AU); (2) 853 MMBO, 1,707 BCFG, and 34 MMBNGL in the continuous Eagle Ford Shale Oil AU; and (3) 50,219 BCFG and 2,009 MMBNGL in the continuous Eagle Ford Shale Gas $A U$ in onshore lands and State waters of the Gulf Coast.

\section{Introduction}

The U.S. Geological Survey (USGS) recently completed a geology-based assessment of the undiscovered, technically recoverable oil and gas resources in Upper Cretaceous strata of the U.S. Gulf Coast region, which includes parts of Texas, Louisiana, Arkansas, Mississippi, Alabama, and Florida (fig. 1). The assessed Upper Cretaceous strata in this report includes the Eagle Ford Group, which is interbedded with laterally equivalent sandstones of the Woodbine and Tuscaloosa Formations; other lateral equivalents are the Eagle Ford Shale, and, in part, the Tuscaloosa marine shale. Nomenclature is a combination of formal and informal groups, and formation and member names that reflect the common designation and usage in the region by State, industry, U.S. Geological Survey, and academic geologists. The assessment was based on the geologic elements and petroleum processes used to define a total petroleum system (TPS), which includes petroleum source rocks (source-rock maturation and petroleum generation and migration), reservoir and seal rocks (sequence stratigraphy and petrophysical properties), and petroleum traps (trap formation, timing, and seals). Using this petroleum-system framework, the USGS defined

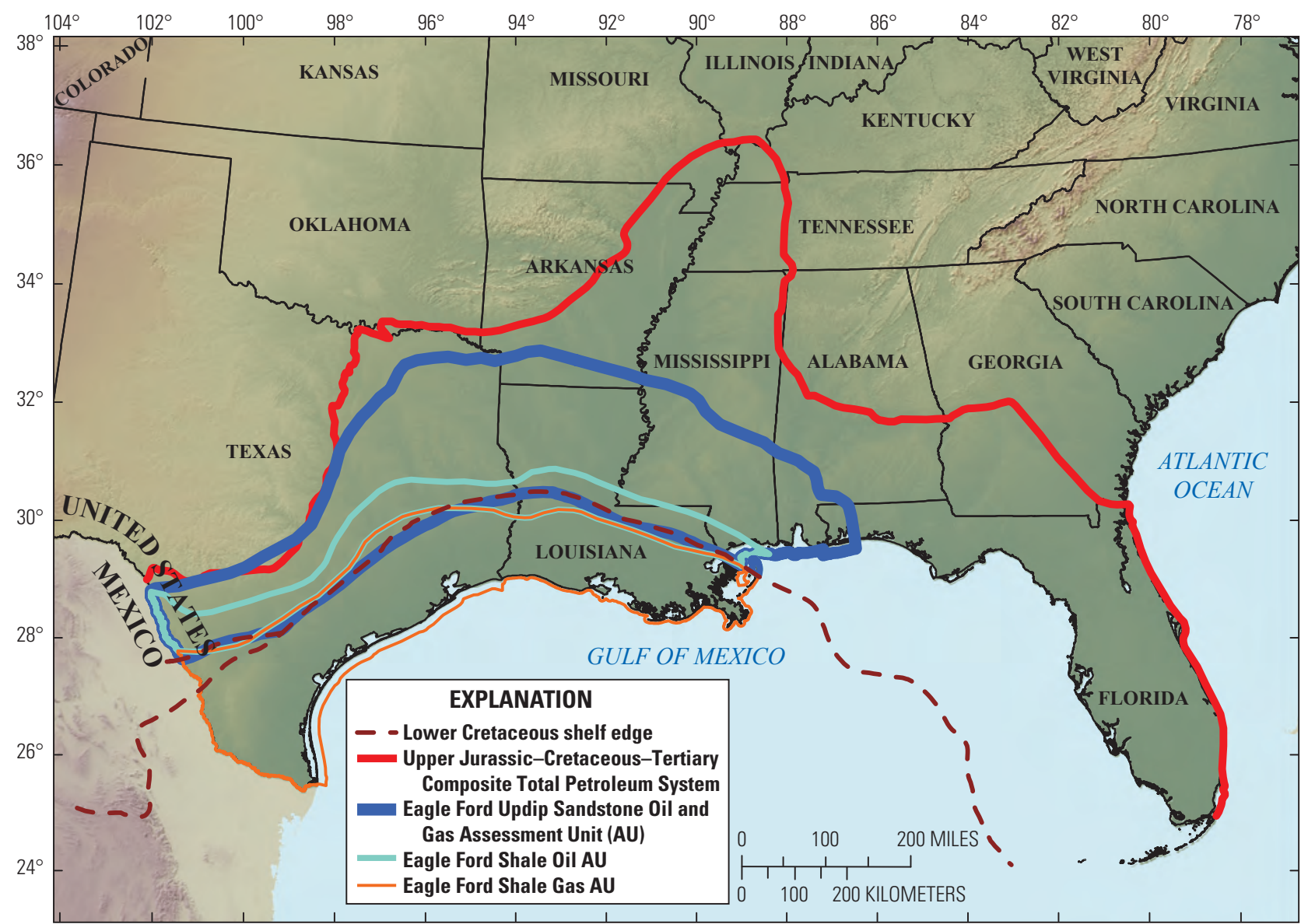

Figure 1. Map of the Gulf Coast region showing part of the Upper Jurassic-Cretaceous-Tertiary Composite Total Petroleum System (red line), assessment unit (AU) boundaries (blue, light blue, and orange lines), and the Lower Cretaceous shelf edge (brown line). Lower Cretaceous shelf edge after Martin (1980) and Ewing and Lopez (1991). 
three assessment units (AUs) for these Cenomanian-Turonian rocks: (1) the Eagle Ford Updip Sandstone Oil and Gas AU, (2) the Eagle Ford Shale Oil AU, and (3) the Eagle Ford Shale Gas AU (fig. 1).

\section{Geologic Summary}

The USGS defined the Upper Jurassic-CretaceousTertiary Composite TPS and three assessment units (AUs) with technically recoverable undiscovered conventional and continuous oil and gas resources in Upper Cretaceous strata (fig. 1). The assessed conventional oil and gas undiscovered resources are in sandstone reservoirs in the Tuscaloosa and Woodbine Formations in Louisiana and Texas, respectively, whereas the continuous oil and continuous gas resources reside in the Eagle Ford Shale in Texas and the Tuscaloosa marine shale in Louisiana. Conventional resources in the Tuscaloosa and Woodbine are included in the Eagle Ford Updip Sandstone Oil and Gas AU, which encompasses an area where the Eagle Ford Shale and Tuscaloosa marine shale display vitrinite reflectance (Ro) values $<0.6$ percent. The conventional gas resources in the socalled "downdip" Tuscaloosa and Woodbine shelf-margin deltas previously were assessed and published in 2007 (Pitman and others, 2007). The continuous Eagle Ford Shale Oil AU lies beneath part of the conventional Eagle Ford Updip Sandstone Oil and Gas AU, immediately updip of the Lower Cretaceous shelf edge, and is defined by thermal maturity values within the Eagle Ford Shale and the Tuscaloosa marine shale that range from 0.6 to 1.2 percent Ro. Similarly, the continuous Eagle Ford Shale Gas AU is defined primarily downdip of the shelf edge where the source rocks have Ro values greater than 1.2 percent.

\section{Resource Summary}

The USGS assessed undiscovered, technically recoverable oil and gas resources in the three assessment units (table 1). The assessed means are (1) 141 million barrels of oil (MMBO), 502 billion cubic feet of natural gas (BCFG), and 16 million barrels of natural gas liquids (MMBNGL) in the conventional Eagle Ford Updip Sandstone Oil and Gas AU; (2) 853 MMBO, 1,707 $\mathrm{BCFG}$, and $34 \mathrm{MMBNGL}$ in the continuous Eagle Ford Shale Oil AU; and (3) 50,219 BCFG and 2,009 MMBNGL in the continuous Eagle Ford Shale Gas AU.

\section{For Further Information}

Supporting geologic studies and the methodology used in the 2010 Jurassic and Cretaceous Gulf Coast Assessment are in progress. Assessment results are available at the USGS Central Energy Resources Science Center website: http://energy.cr.usgs. gov/oilgas/noga.

\section{References Cited}

Martin, R.G., 1980, Distribution of salt structures, Gulf of Mexico: U.S. Geological Survey Miscellaneous Field Studies Map MF-1213, scale $1: 2,500,000$.

Ewing, T.E., and Lopez, R.F., 1991, Principal structural features, in Salvador, A., ed., The Gulf of Mexico Basin: The Geological Society of America, The Geology of North America, v. J, plate 2.

Pitman, J.K., Dubiel, R.F., Nelson, P.H., Kibler, Joyce, Charpentier, R.R., Cook, T.A., Klett, T.R., Pollastro, Richard, and Schenk, C.J., 2007, Assessment of undiscovered gas resources in the Upper Cretaceous Tuscaloosa and Woodbine Formations, Western Gulf Province of the Gulf Coast region, Louisiana and Texas, 2007: U.S. Geological Survey Fact Sheet 2006-3146.

\section{Assessment Team}

Russell F. Dubiel (rdubiel@usgs.gov), Janet K. Pitman, Ofori N. Pearson, Krystal Pearson, Scott A. Kinney, Michael D. Lewan, Lauri Burke, Laura R.H. Biewick, Ronald R. Charpentier, Troy A. Cook, Timothy R. Klett, Richard M. Pollastro, and Christopher J. Schenk.

Table 1. Eagle Ford assessment results.

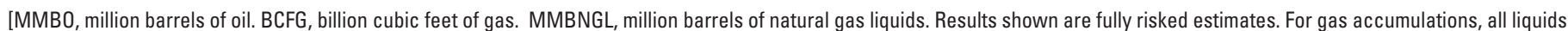
are included as NGL (natural gas liquids). F95 represents a 95-percent chance of at least the amount tabulated; other fractiles are defined similarly. Fractiles are additive under the assumption of perfect positive correlation. TPS, total petroleum system; AU, assessment unit. Gray shading indicates not applicable]

\begin{tabular}{|c|c|c|c|c|c|c|c|c|c|c|c|c|c|}
\hline \multirow{3}{*}{$\begin{array}{l}\text { Total Petroleum Systems } \\
\text { (TPS) } \\
\text { and Assessment Units (AU) }\end{array}$} & \multirow{3}{*}{$\begin{array}{l}\text { Field } \\
\text { type }\end{array}$} & \multicolumn{12}{|c|}{ Total undiscovered resources } \\
\hline & & \multicolumn{4}{|c|}{ Oil (MMBO) } & \multicolumn{4}{|c|}{ Gas (BCFG) } & \multicolumn{4}{|c|}{ NGL (MMBNGL) } \\
\hline & & F95 & F50 & F5 & Mean & F95 & F50 & F5 & Mean & F95 & F50 & F5 & Mean \\
\hline \multicolumn{14}{|c|}{ Upper Jurassic-Cretaceous-Tertiary Composite TPS (504901) } \\
\hline \multirow{2}{*}{$\begin{array}{l}\text { Eagle Ford Updip Sandstone Oil } \\
\text { and Gas AU (50490128) }\end{array}$} & Oil & 41 & 136 & 253 & 141 & 53 & 184 & 381 & 197 & 1 & 4 & 8 & 4 \\
\hline & Gas & & & & & 86 & 289 & 571 & 305 & 3 & 11 & 24 & 12 \\
\hline $\begin{array}{l}\text { Total conventional } \\
\text { resources }\end{array}$ & & 41 & 136 & 253 & 141 & 139 & 473 & 952 & 502 & 4 & 15 & 32 & 16 \\
\hline $\begin{array}{l}\text { Eagle Ford Shale Oil AU } \\
(50490170)\end{array}$ & Oil & 341 & 758 & 1,687 & 853 & 625 & 1,486 & 3,533 & 1,707 & 12 & 29 & 74 & 34 \\
\hline $\begin{array}{l}\text { Eagle Ford Shale Gas AU } \\
(50490167)\end{array}$ & Gas & & & & & 23,470 & 46,150 & 90,747 & 50,219 & 851 & 1,809 & 3,842 & 2,009 \\
\hline $\begin{array}{l}\text { Total continuous } \\
\text { resources }\end{array}$ & & 341 & 758 & 1,687 & 853 & 24,095 & 47,636 & 94,280 & 51,926 & 863 & 1,838 & 3,916 & 2,043 \\
\hline $\begin{array}{l}\text { Total undiscovered } \\
\text { oil and gas resources }\end{array}$ & & 382 & 894 & 1,940 & 994 & 24,234 & 48,109 & 95,232 & 52,428 & 867 & 1,853 & 3,948 & 2,059 \\
\hline
\end{tabular}

